Acta vet. scand. $1986,27,209-222$.

From the Department of Animal Hygiene, College of Veterinary Medicine, Helsinki, and the Finnish Animal Breeding Association, Vantaa, Finland.

\title{
AN EPIDEMIOLOGICAL AND GENETIC STUDY ON REGISTERED DISEASES IN FINNISH AYRSHIRE CATTLE
}

\author{
III. METABOLIC DISEASES
}

By

Yrjö Gröhn, Hannu Saloniemi and Jouko Syväjärvi

\begin{abstract}
GRÖHN, YRJÖ, HANNU SALONIEMI and JOUKO SYVÄJÄRVI: An epidemiological and genetic study on registered diseases in Finnish Ayrshire cattle. III. Metabolic diseases. Acta vet. scand. 1986, 27, 209-222. - The epidemiology of clinical ketosis, hypocalcaemia and hypomagnesaemia was examined. In addition, the genetic variability of ketosis and parturient paresis was investigated. The data set consisted of the lactation records of 70,775 Finnish Ayrshire dairy cows. Each cow was under observation for 2 days before and for 305 days after calving. Lactation incidence rates $(\%)$ were: ketosis 6.0 , parturient paresis 3.8 , non-parturient paresis 0.6 , hypomagnesaemic tetany, outdoor 0.6 , and indoor 0.2 . These diseases formed $22 \%$ of all first treatments by veterinarians during farm visits. $92 \%$ of the cases of ketosis occurred with 8 weeks of parturition, with the highest occurrence 3-5 weeks after calving. Four \% of cases of parturient paresis occurred before, and $45 \%$ within $24 \mathrm{~h}$ after calving. When cases were categorized by month of calving the risk of ketosis was higher during indoor feeding (October-April) than during outdoor feeding (May-September). The risk of parturient paresis did not significantly vary with month of calving. The occurrence of ketosis increased with parity up to the 4 th and decreased thereafter. The occurrence of parturient paresis increased with parity. Both the increase in herd milk yield and the increase in individual milk yields were positively associated with the occurrence of ketosis and parturient paresis. The cows with a history of the reproductive tract infection had a higher risk of contracting ketosis. Heritability estimates for ketosis in various parity groups were from $1.6 \%$ to $4.1 \%$ on the binomial scale (corresponding to $7.3 \%-14.4 \%$ on the normal scale), and for parturient paresis from 3.5 to $10.5 \%$ (corresponding from $18.3 \%$ to $27.4 \%$ ). The genetic correlation between ketosis and parturient paresis, and these and current milk production for all material were insignificant.
\end{abstract}

disease documentation; heritability; ketosis; parturient paresis; non-parturient paresis; hypomagnesaemic tetany; dairy cows. 
Past successes in preventive veterinary medicine have made possible intensive animal production systems (Schwabe 1982). In the current dairy industry there are three main disease complexes that are less dramatic but require understanding of multifactorial diseases: reproductive disorders, metabolic diseases and mastitis. All of these diseases have been and still are the subject of intensive research. The clinical picture, aetiology and pathogenesis of the most common metabolic diseases have been reviewed thoroughly (see e.g. Littledike et al. 1981). In recent years the research interest in epidemiology of metabolic diseases has increased (Øverby et al. 1974, Saloniemi \& Roine 1981, Solbu 1983, Dohoo et al. 1983, Curtis et al. 1984). The investigators have also been interested in the heritability of susceptibility to metabolic diseases (O'Bleness et al. 1960, Van Vleck 1964, Norman \& Van Vleck 1972, Dyrenthal et al. 1972). To date the main reason for limited research regarding the genetic determination of metabolic diseases has been the lack of sufficient health data on the scale necessary for a study of this kind. With the institution of more sophisticated disease registry systems, the number of genetic studies of these diseases has increased (Solbu 1984, Gröhn et al. 1984, Dohoo \& Martin 1984).

In our previous papers, the data set, the occurrence of the most common dairy cow diseases, the effects of possible risk factors on culling (Gröhn et al. 1986), and the epidemiology and genetic variability of reproductive disorders (Saloniemi et al. 1986) were investigated. The purpose of the current work was to examine the epidemiology and genetic variability of ketosis and parturient paresis in Finnish Ayrshire cattle. In addition, the objective was to investigate the occurrence of non-parturient paresis and outdoor and indoor hypomagnesaemic tetany.

\section{MATERIALS AND METHODS}

Data

The data used in this study have been presented previously (Gröhn et al. 1986). The lactation records of 70,775 Finnish Ayrshire dairy cows were complete. The cows that calved during the period between January 1, 1983 and December 31, 1983 were under observation for 2 days before and for 305 days after calving. The cows belonged to the milk registry and health and pedigree data were available. The data included only those cases 
treated by veterinarians during farm visits. The metabolic diseases studied were: ketosis, parturient and non-parturient paresis, and hypomagnesemic tetany outdoor and indoor. The diagnoses were made according to ordinary clinical methods in field conditions. Only the first diagnoses were considered, and repeated treatments or treatments by telephone prescription were excluded.

\section{Statistical analysis}

All statistical analyses were carried out using the Statistical Analyses System (Ray 1982). The occurrence of a metabolic disease was expressed using the term lactation incidence rate (Erb \& Martin 1980). The possible effects of certain factors on contracting ketosis or parturient paresis were determined using a logistic regression model (Cox 1970, Feinberg 1980).

For genetic analysis, sire and error components of variance and covariances were recomputed by using the following least square model: $Y_{i j k l m}=\mu+a_{i}+c_{j}+m_{k}+s_{l}+e_{i j k l m}$, where $\mathrm{Y}=$ the disease in question recorded as 1 or 0 depending whether the cow has been treated or not by a veterinarian. For estimates of covariances the summed trait of diseases and 305day milk yield were also analysed as dependent variables. The milk yield was expressed as the deviation from the mean of the herd milk production level;

$\mu=$ the theoretical mean;

$a_{i}=$ the effect of the ith age class at calving (age at calving was grouped for the cows in the first parity $<751 ; 751-841 ;>841$ days, in the second parity $<1,111 ; 1,111-1,200$ and $>1,200$ days, and in the other parities the parity grouping $3-4,5-6$ and $>6$ was used);

$c_{j}=$ the effect of the $j$ th calving season (grouped as JanuaryApril, May-August and September-December);

$\mathbf{m}_{\mathrm{k}}=$ the effect of $\mathrm{kth}$ herd milk production class (the mean of 305-day milk production of the cows in the herd grouped as $<4,870 ; 4,870-6,150$ and $>6,150 \mathrm{~kg}$ );

$s_{1}=$ the effect of the cow's sire;

$\mathbf{e}_{\mathrm{ijklm}}=\mathbf{a}$ residual component.

All factors were considered fixed except sire and error term, which were considered random. The analyses were also done by absorbing the herd effects. Because the absorption had only a 
slight effect on the estimates of heritabilities, the results are given without the absorption in these analyses. The analysis was carried out separately for each parity group and for all parities together. Only those sires with more than 25 daughters within each parity group, and the sires with more than 50 daughters for the total material were included in genetic analyses. Error and sire covariances were estimated as half the difference between the respective variances of the summed traits minus each of respective variances of the traits. The genetic correlations, uncorrected and corrected heritabilities and standard errors were computed using the methods described previously (Gröhn et al. 1986).

\section{RESULTS}

Lactation incidence rates for some metabolic diseases in relation to parity are given in Table 1. All of these diseases increased with parity, except ketosis which decreased after the 4th parity and hypomagnesaemic tetany after the 6th parity. These diseases made up $21.6 \%$ of all first treatments by veterinarians. Ketosis and parturient paresis were the most common metabolic diagnoses.

T a b l e 1. Lactation incidence rate (\%) of some metabolic diseases in relation to parity in 70,775 Finnish Ayrshire cows.

\begin{tabular}{|c|c|c|c|c|c|c|c|}
\hline \multirow{2}{*}{ Disease } & \multicolumn{5}{|c|}{ Parity } & \multirow[b]{2}{*}{ All } & \multirow{2}{*}{$\begin{array}{l}\% \text { of all first } \\
\text { treatment }\end{array}$} \\
\hline & $\mathbf{1}$ & 2 & $3-4$ & $5-6$ & $>6$ & & \\
\hline Ketosis & 4.37 & 5.14 & 7.87 & 7.38 & 5.04 & 6.0 & 12.0 \\
\hline Parturient paresis & 0.05 & 0.40 & 3.94 & 10.79 & 12.23 & 3.8 & 7.6 \\
\hline $\begin{array}{l}\text { Non-parturient } \\
\text { paresis }\end{array}$ & 0.10 & 0.30 & 0.64 & 1.05 & 1.54 & 0.6 & 1.2 \\
\hline $\begin{array}{l}\text { Hypomagnesaemic } \\
\text { tetany, outdoor }\end{array}$ & 0.08 & 0.15 & 0.41 & 0.56 & 0.45 & 0.3 & 0.6 \\
\hline $\begin{array}{l}\text { Hypomagnesaemic } \\
\text { tetany, indoor }\end{array}$ & 0.07 & 0.09 & 0.19 & 0.22 & 0.11 & 0.1 & 0.2 \\
\hline
\end{tabular}

In general, calvings were equally distributed throughout the year, except for an increase in March, April and May and a slight decrease in June and July (Table 2). The monthly distribution of treated cases of ketosis and parturient paresis partly reflected calving distribution (Table 2). When cases were categorized by 
T a b l e 2. Monthly distribution of calvings, treated cases of ketosis and parturient paresis, and the risk of ketosis and parturient paresis by month of calving for 70,775 Finnish Ayrshire cows.

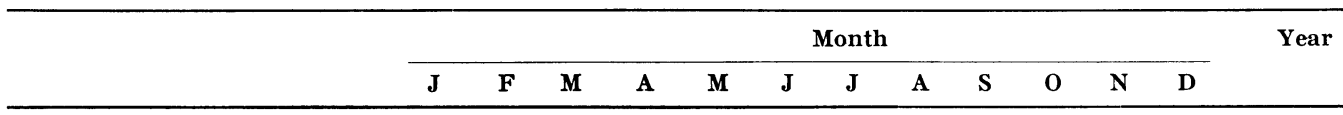

Calvings per month

( $\%$ of yearly total)

$\begin{array}{lllllllllllll}6.9 & 6.7 & 10.6 & 14.2 & 9.9 & 6.5 & 5.7 & 7.4 & 7.8 & 8.9 & 8.7 & 7.5 & 100.0\end{array}$

Ketosis cases per month

(\% of yearly total)

$\begin{array}{lllllllllllll}9.1 & 10.4 & 17.1 & 18.5 & 4.0 & 1.3 & 1.1 & 2.4 & 5.2 & 8.7 & 9.9 & 12.3 & 100.0\end{array}$

Risk of ketosis by

$\begin{array}{llllllllllllll}\text { month of calving (\%) } & 7.9 & 9.4 & 9.7 & 7.9 & 2.4 & 1.2 & 1.1 & 2.0 & 4.0 & 5.9 & 7.7 & 9.8 & 6.0\end{array}$

Parturient paresis

cases per month

( $\%$ of yearly total)

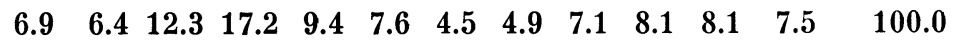

Risk of parturient

paresis by month

of calving $(\%)$

$\begin{array}{llllllllllll}3.8 & 3.7 & 4.4 & 4.6 & 3.6 & 4.4 & 3.0 & 2.5 & 3.4 & 3.5 & 3.9 & 3.8\end{array}$

month of calving the risk of ketosis was higher during indoor feeding (October-April) than during outdoor feeding (May-September) (Table 2). In the logit regression model calving season was a significant factor in explaining the probability of contracting ketosis (Table 4). The risk of parturient paresis did not significantly vary by month of calving (Table 2 ). $4 \%$ of parturient paresis cases occurred before, and $45 \%$ within $24 \mathrm{~h}$ after calving (Table 3 ). $92 \%$ of ketosis cases occurred within 8 weeks after parturition, with the highest occurrence $3-5$ weeks after calving (Table 3 ).

T a b l e 3. Weeks post partum of occurrence of clinical ketosis and days pre and post partum of occurrence of parturient paresis for 70,775 Finnish Ayrshire cows.

\begin{tabular}{|c|c|c|c|c|c|c|c|c|c|c|}
\hline \multirow[t]{2}{*}{ Cases of ketosis } & \multicolumn{10}{|c|}{ Weeks post partum } \\
\hline & 1 & 2 & 3 & 4 & 5 & 6 & 7 & 8 & 9 & $10-12$ \\
\hline Percentage of total & 4.1 & 10.0 & 16.0 & 21.6 & 17.6 & 11.3 & 6.7 & 4.2 & 2.3 & 3.3 \\
\hline Cumulative percentage & 4.1 & 14.1 & 30.1 & 51.7 & 69.3 & 80.6 & 87.3 & 91.5 & 93.8 & 97.1 \\
\hline \multirow{2}{*}{$\begin{array}{l}\text { Cases of parturient } \\
\text { paresis }\end{array}$} & \multicolumn{10}{|c|}{ Days pre and post partum } \\
\hline & -2 & -1 & $\mathbf{0}$ & 1 & 2 & 3 & 4 & 5 & 6 & 7 \\
\hline Percentage of total & 0.8 & 3.5 & 44.9 & 33.3 & 9.4 & 2.5 & 1.5 & 1,1 & 2.0 & 1.0 \\
\hline Cumulative percentage & 0.8 & 4.3 & 49.2 & 82.5 & 91.9 & 94.4 & 95.9 & 97.0 & 99.0 & 100.0 \\
\hline
\end{tabular}


The logistic regression model selected to explain the probability of contracting ketosis included 5 main effects: parity, calving season, herd class average for milk, cow's milk yield as the deviation from the mean of herd's milk production level and the history of the reproductive tract infection. The $\mathrm{G}^{2}$ statistic for this model was 347.6 with 304 degrees of freedom ( $\mathrm{P}=$ 0.0432); the P-value indicates that there are other factors than those in the model, which may improve the fit. However, for large sets of data the $\mathrm{G}^{2}$-statistic tends to reject virtually any model, thus being of limited value for practical purposes. Here the ratio of $\mathrm{G}^{2}$ to the degree of freedom is near to one (expectation under a good model) and the easy interpretation of the model motivates its use. The model selected to explain contracting parturient paresis included the same main effects, except calving season and the history of reproductive tract infection. The $G^{2}$ statistic for this model was insignificant $(P=0.2801)$, implying a reasonable fit to the data.

All main effects in both models were significant and further inclusion of main effects did not substantially improve the fit.

Table 4 lists the estimated values for the main effect parameters in the logistic regression model for the probability of contracting ketosis. For instance, the cows with parity 3-4, spring calving season, highest herd milk yield and highest cow's milk yield and with the history of infection of the reproductive tract post partum had the highest expected odds of contracting ketosis of $\mathrm{e}^{(-2.567+0.243+0.638+0.192+0.158+0.452)}=\mathrm{e}^{-0.884}=0.413$ (equivalent to a $29.2 \%$ chance of contracting ketosis). The lowest odds were for the cows with parity $>6$, summer calving, lowest herd milk yield, lowest cow's milk yield and without the history of reproductive tract infection of $\mathrm{e}^{(-2.567-0.265-0.990-0.186}$ $-0.163-0.452)=e^{-4.623}=0.0098$ (equivalent to a $1.0 \%$ chance of contracting ketosis). The odds ratio comparing the odds is $0.413 / 0.0098=42.2$. This means that cows with a combination of the highest risk variables are 42.2 times as likely to contract ketosis as those with the combination of lowest risk variables. Similar comparisons can be made by forming such ratios between any two combination groups and using the denominator as the comparison level. Table 4 lists the estimated odds (probabilities in parenthesis) of contracting ketosis, as well. The estimated odds and probabilities are conditional on the given factor level and adjusted for the other factors. The odds ratios computed from Table 4 are stable over all levels of other factors. 
Table 4. Estimates of the parameters included in the logit model used in the analysis of contracting ketosis for 51,449 Finnish Ayrshire cows (cows in first lactation excluded).

\begin{tabular}{|c|c|c|c|}
\hline \multirow{2}{*}{$\frac{\text { Parameter }}{\text { Intercept }}$} & \multirow{2}{*}{$\begin{array}{c}\text { Estimated value } \\
-2.567\end{array}$} & \multicolumn{2}{|c|}{ Estimated odds a } \\
\hline & & 0.077 & (7.2) \\
\hline \multicolumn{4}{|l|}{ Parity } \\
\hline \multicolumn{4}{|l|}{ - } \\
\hline 2 & -0.102 & 0.069 & (6.5) \\
\hline $3-4$ & 0.243 & 0.098 & (8.9) \\
\hline $5-6$ & 0.124 & 0.087 & (8.0) \\
\hline$>6$ & -0.265 & 0.059 & (5.6) \\
\hline \multicolumn{4}{|l|}{ Calving season } \\
\hline January-April & 0.638 & 0.145 & (12.7) \\
\hline May-August & -0.990 & 0.029 & $(2.8)$ \\
\hline September-December & 0.352 & 0.109 & $(9.8)$ \\
\hline \multicolumn{4}{|l|}{$\begin{array}{l}\text { Herd milk yield in } \\
\text { previous lactation }(\mathrm{kg})\end{array}$} \\
\hline$<4870$ & -0.186 & 0.064 & $(6.0)$ \\
\hline$<6150$ & -0.006 & 0.076 & (7.1) \\
\hline$\geq 6150$ & 0.192 & 0.093 & (8.5) \\
\hline \multicolumn{4}{|c|}{$\begin{array}{l}\text { Cow's milk yield in previous } \\
\text { lactation (the deviation from } \\
\text { the mean, } \mathrm{kg} \text { ) }\end{array}$} \\
\hline$<-1000$ & -0.163 & 0.065 & (6.1) \\
\hline$<-500$ & -0.158 & 0.066 & (6.2) \\
\hline$<\quad 500$ & 0.032 & 0.079 & (7.3) \\
\hline$<1000$ & 0.131 & 0.088 & (8.1) \\
\hline$\geq 1000$ & 0.158 & 0.090 & (8.3) \\
\hline \multicolumn{4}{|c|}{$\begin{array}{l}\text { Infection of the reproductive } \\
\text { tract post partum }<42 \text { days }\end{array}$} \\
\hline yes & 0.452 & 0.121 & (10.8) \\
\hline no & -0.452 & 0.049 & $(4.7)$ \\
\hline
\end{tabular}

a The estimated odds (probabilities in parenthesis) are for contracting ketosis conditional on the given factor level and adjusted for the other factors.

In Table 5 the estimated values, odds and probabilities of contracting parturient paresis are given. The cows with parity $>6$, highest herd milk yield and highest cow milk yield had the highest odds of contracting parturient paresis. The lowest odds are for the cows with parity 2 , lowest herd milk yield and lowest cow milk yield.

The estimates of heritabilities for ketosis and parturient paresis and genetic correlations between those and milk produc- 
T a ble 5. Estimates of the parameters included in the logit model used in the analysis of contracting parturient paresis for 51,449 Finnish Ayrshire cows (cows in first lactation excluded).

\begin{tabular}{lccc}
\hline Parameter & Estimated value & \multicolumn{3}{c}{ Estimated odds ${ }^{\mathrm{a}}$} \\
\hline Intercept & -3.251 & 0.039 & $(3.8)$ \\
Parity & & & \\
- & & & \\
2 & -2.235 & 0.004 & $(0.4)$ \\
$3-4$ & -0.011 & 0.038 & $(3.7)$ \\
$5-6$ & 1.041 & 0.110 & $(9.9)$ \\
$>6$ & 1.205 & 0.129 & $(11.4)$ \\
Herd milk yield in & & & \\
previous lactation (kg) & & & \\
$<4870$ & -0.417 & 0.026 & $(2.5)$ \\
$<6150$ & 0.058 & 0.041 & $(3.9)$ \\
$\geq 6150$ & 0.359 & 0.056 & $(5.3)$ \\
Cow's milk yield in previous & & & \\
lactation (the deviation from & & & \\
the mean, kg) & & & \\
$<-1000$ & -0.146 & & \\
$<-500$ & -0.085 & 0.034 & $(3.3)$ \\
$<\quad 500$ & -0.002 & 0.036 & $(3.5)$ \\
$<\quad 1000$ & 0.067 & 0.039 & $(3.8)$ \\
$>1000$ & 0.166 & 0.041 & $(3.9)$ \\
\hline
\end{tabular}

a The estimated odds (probabilities in parenthesis) are for contracting parturient paresis conditional on the given factor level and adjusted for the other factors.

tion in the current lactation are given in Table 6. Heritability estimates for ketosis and parturient paresis differed clearly from zero. The estimate for parturient paresis increased with parity. Genetic correlations between ketosis and parturient paresis, and these and current milk production were inconsistent in various parity groups and the correlations for the total material were insignificant.

\section{DISCUSSION}

A common feature for ketosis, hypocalcaemia and hypomagnesaemia is the imbalance between the supply of nutrients and the requirements of the animal (Littledike et al. 1981). Intensive selection for milk yield can be assumed to narrow the nutritional and managerial spectrum over which the animals can maintain metabolite homeostasis. Therefore, it is important to register all 
Table 6. Estimates of heritabilities $\left(h^{2}\right)$ for ketosis and parturient paresis and genetic correlations ( $\mathrm{rg}$ ) between those and milk production in current lactation for Finnish Ayrshire cattle.a, b, c

\begin{tabular}{|c|c|c|c|c|c|c|}
\hline & \multicolumn{6}{|c|}{ Parity } \\
\hline & 1 & 2 & $3-4$ & $5-6$ & $>6$ & All \\
\hline Number of sires & 190 & 150 & 178 & 45 & 22 & 259 \\
\hline $\begin{array}{l}\text { Mean number of } \\
\text { daughters per sire }\end{array}$ & 70 & 62 & 61 & 60 & 47 & 127 \\
\hline $\begin{array}{l}\text { Ketosis } \\
\mathrm{h}^{2} \text { uncolrected } \\
\text { standard error } \\
\mathrm{h}^{2} \text { corrected }\end{array}$ & $\begin{array}{l}0.016 \\
0.008 \\
0.078\end{array}$ & $\begin{array}{l}0.016 \\
0.009 \\
0.073\end{array}$ & $\begin{array}{l}0.026 \\
0.010 \\
0.088\end{array}$ & $\begin{array}{l}0.041 \\
0.023 \\
0.144\end{array}$ & $\begin{array}{l}0.020 \\
0.034 \\
0.089\end{array}$ & $\begin{array}{l}0.021 \\
0.005 \\
0.084\end{array}$ \\
\hline $\begin{array}{l}\text { Parturient paresis } \\
\mathrm{h}^{2} \text { uncorrected } \\
\text { standard error } \\
\mathrm{h}^{2} \text { corrected } \\
\text { Genetic correlations }\end{array}$ & N.E. & I.E. & $\begin{array}{l}0.035 \\
0.018 \\
0.183\end{array}$ & $\begin{array}{l}0.087 \\
0.033 \\
0.244\end{array}$ & $\begin{array}{l}0.105 \\
0.058 \\
0.274\end{array}$ & $\begin{array}{l}0.038 \\
0.006 \\
0.204\end{array}$ \\
\hline $\begin{array}{l}\text { Ketosis } \times \text { parturient } \\
\text { paresis } \\
\text { standard error }\end{array}$ & N.E. & I.E. & $\begin{array}{l}0.062 \\
0.240\end{array}$ & $\begin{array}{r}-0.216 \\
0.314\end{array}$ & $\begin{array}{r}-0.783 \\
0.253\end{array}$ & $\begin{array}{r}-0.068 \\
0.132\end{array}$ \\
\hline $\begin{array}{l}\text { Ketosis } \times \text { milk } \\
\text { yield } \\
\text { standard error }\end{array}$ & $\begin{array}{l}0.297 \\
0.147\end{array}$ & $\begin{array}{l}0.185 \\
0.206\end{array}$ & $\begin{array}{l}0.196 \\
0.160\end{array}$ & $\begin{array}{r}-0.292 \\
0.263\end{array}$ & I.E. & $\begin{array}{l}0.100 \\
0.103\end{array}$ \\
\hline $\begin{array}{l}\text { Parturient } \\
\text { paresis } \times \text { milk } \\
\text { yield } \\
\text { standard error }\end{array}$ & N.E. & I.E. & $\begin{array}{r}-0.052 \\
0.148\end{array}$ & $\begin{array}{r}-0.432 \\
0.189\end{array}$ & I.E. & $\begin{array}{r}-0.088 \\
0.088\end{array}$ \\
\hline
\end{tabular}

a The correction was made by the multiplication factor $P(1-P) / z^{2}$, where $P$ was the incidence of the disease and $z$ the height of the ordinate of the normaldistribution at that incidence.

b N.E. = not estimated due to the extremely low lactation incidence rate.

c $\mathbf{I} . \mathrm{E}=$ illogical estimate.

changes in the occurrence of these diseases, to investigate effects of possible risk factors and the genetic variation. From a breeding point of view the most important question is to know the genetic correlation between disease susceptibility and production ability.

In this study the incidence rates for ketosis $(6.0 \%)$ and nonparturient paresis $(0.6 \%)$ are approximately the same as, that for hypomagnesaemic tetany (outdoor $0.6 \%$ and indoor $0.2 \%$ ) is higher than, and that for parturient paresis $(3.8 \%)$ is lower 
than in a previous Finnish paper (Saloniemi \& Roine 1981). The rates for ketosis and parturient paresis are higher in Norway (Solbu 1983) and lower or approximately the same in Sweden (Bäckström et al. 1975) and Denmark (Elleby et al. 1969).

For ketosis the period of highest risk was 3-5 weeks after calving as reported earlier (Øverby et al. 1974, Gröhn et al.1983). Dohoo et al. (1983) found an earlier occurrence than we did. The occurrence of parturient paresis in relation to calving agrees with a finding by Dyrendahl et al. (1972).

A real seasonal pattern in the risk of ketosis by month of calving (Table 2) was verified by a logistic regression model (Table 4). The risk of ketosis was higher during indoor feeding (October-April) than during outdoor feeding (May-September). Variation in the risk of parturient paresis by month of calving was not apperent as reported by Ekesbo (1966) and Saloniemi $\&$ Roine (1981). The effects of parity were investigated by determining both lactation incidence rates in the various parity groups, (Table 1) and by estimating odds in the logit model (Tables 4 and 5). The incidence rate of clinical ketosis has been reported to peak in the age ranges 4-7 years (Erb \& Martin 1978), 5-8 years (Øverby et al. 1974) and at 9 years (Dohoo \& Martin 1984). The peak in this study was at parity 3-4 (approximately $5-6$ years of age). The increase of the risk of parturient paresis with parity supports findings by Dyrendahl et al. (1972) and Dohoo \& Martin (1984).

Both the increase in herd milk yield and the increase in individual cow's milk yield increased the risk of ketosis and parturient paresis (Tables 4 and 5). Although there are other reports (Pehrsson 1966, Øverby et al. 1974, Solbu 1983) supporting this finding, it is difficult to interpret the significance of the connection between milk yield and ketosis or parturient paresis. This difficulty has been discussed in a previous paper (Gröhn et al. 1984). Assuming that the association between milk yield and ketosis and parturient paresis is real and does not just reflect better care for the higher yielders, other explanations may be discussed. A genetic analysis may also clarify this question.

The sire components and the heritability estimates for susceptibility to ketosis and parturient paresis were relatively high (Table 6). However, neither a genetic correlation between ketosis and parturient paresis, nor between these and current milk production differed clearly from zero. This may imply that the 
observed association between milk yield and ketosis, or between milk yield and parturient paresis are mainly phenotypic. About $25 \%$ of the variation in milk production results from genetic differences. High yielders are phenotypically more susceptible to ketosis and parturient paresis because their nutritional requirements may not be satisfied. In future research accurate feeding and management data should be included in the studies of metabolic diseases.

From a statistical point of view, as discussed earlier (Gröhn et al. 1984), one difficulty is to handle threshold characteristics. The logit regression methodology is an appropriate technique for analysing a binary response factor. However, our approach in genetic analyses was to use traditional animal genetics methodology (linear model) on the binomial scale for probability of occurrence of a disease, and then to convert binomial heritability estimates to estimates on the normal scale. The treatment occurrences are typically all-or-none traits and the underlying assumption about normality is not fulfilled in the data although the assumption about normality of genotypes may still be realistic. Thus, prediction and estimation procedures based on normality are approximative and may yield poor results (Portnoy 1982, Mejering 1985).

The findings in the current study indicate that there is a genetic component in the aetiology of ketosis and parturient paresis. It seems reasonable to consider at least ketosis in the progeny testing of bulls. The low incidence of parturient paresis in younger animals hinders the inclusion of this trait in the current breeding program. Providing that the linear model in the genetic analysis gave reliable results, the association between these diseases and milk yield is mainly phenotypic. Thus, selection for milk yield does not genetically increase the incidence of these diseases. The management and nutritional requirements of higher yielding animals have to be considered appropriately. The epidemiological findings in this study are only a base enabling understanding of metabolic diseases and further research in feeding and management is clearly necessary.

\section{AGKNOWLEDGEMENTS}

The authors thank Pol. Lic. Juni Palmgren for advice on logistic regression, and the Agricultural Data Processing Centre for supplying computer facilities for statistical analysis. 


\section{REFERENCES}

Bäckström, L., J. Mattsson, O. Wallin \& B. Vilson: Praktikjournalförsöket i Skaraborgs län 1971-1973. (Practice journal experiment in the county of Skaraborg 1971-1973). Svensk. Vet.-Tidn. 1975, $27,238-250,292-300$.

Cox, D. R.: Analysis of Binary Data. Chapman and Hall, London 1970.

Curtis, C. R., H. N. Erb, C. J. Sniffen \& R. D. Smith: Epidemiology of parturient paresis: predisposing factors with emphasis on dry cow feeding and management. J. Dairy Sci. 1984, 67, 817-825.

Dohoo, I. R., S. W. Martin, I. McMillan \& B. W. Kennedy: Disease, production and culling in Holstein-Friesian cows. II. Age, season and sire effects. Prev. Vet. Med. 1984, 2, 655-670.

Dohoo, I. R., S. W. Martin, A. H. Meek \& W. C. D. Sandals: Disease, production and culling in Holstein - Friesian cows. I. The data. Prev. Vet. Med. 1983, 1, 321-334.

Dyrendahl, I., B. Henricson \& G. Jönsson: Clinical puerperal paresis and hypocalcaemia in cattle. A statistical and genetic investigation. Zbl. vet. med., A, 1972, 19, 621-638.

Ekesbo, I.: Disease incidence in tied and loose housed dairy cattle. Acta agric. scand. 1966, Suppl. 15.

Elleby, F., P. Jochumsen \& N. H. Veirup: Forekomst af kvægsygdomme i 6 danske kontrolforeninger i 1967/68. (Disease incidence within six Danish milk recording societies). Kgl. Vet.- og Landbohøjsk. Inst. Sterilitetsforskn. Aarsberetn. 1969, p. 77-90.

Erb, H. N. \& S. W. Martin: Relationships between production and reproductive diseases in Holstein cows. Data. J. Dairy Sci. 1980, $63,1911-1917$.

Feinberg, S. E.: The Analysis of Cross-Classified Categorical Data. 2nd ed. MIT Press, Cambridge, Massachusets 1980.

Gröhn, Y., H. Saloniemi \& J. Syväjärvi: An epidemiological and genetic study on registered diseases in Finnish Ayrshire cattle. I. The data, disease occurrence and culling. Acta vet. scand. 1986, 27, $182-195$.

Gröhn, Y., J. R. Thompson \& M. L. Bruss: Epidemiology and genetic basis of ketosis in Finnish Ayrshire cattle. Prev. Vet. Med. 1984, $3,65-77$.

Littledike, E. T., J. W. Young \& D. C. Beitz: Common metabolic disease of cattle: ketosis, milk fever, grass tetany, and downer cow complex. J. Dairy Sci. 1981, 64, 1465-1482.

Meijering, A.: Practical aspects in the estimation of parameters and breeding values for all-or-none traits. 36th Ann. Meet. Europ. Assoc. Animal Product., Kallithea, Greece 1985.

Norman, H. D. \& L. D. Van Vleck: Type appraisal: II. Variation in type traits due to sires, herds, and years. J. Dairy Sci. 1972, 55, $1717-1725$.

O'Bleness, G. V., L. D. Van Vleck \& C. R. Henderson: Heritabilities of some type appraisal traits and their genetic and phenotypic correlations with production. J. Dairy Sci. 1960, 43, 1490-1498. 
Øverby, I., M. Aas Hansen, K. Jonsgård \& E. Sognen: Bovine ketosis. I. Occurrence and incidence in herds affected by ketosis in Eastern Norway 1965-1968. Nord. Vet.-Med. 1974, 26, 353-361.

Pehrsson, B.: Studies on ketosis in dairy cows. Acta vet. scand. Suppl. $15,1966$.

Portnoy, S.: Maximizing the probability of correctly ordering random variables using linear predictors. J. Mult. Anal. 1982, 12, 256269.

Ray, A. A.: SAS User's Guide: Statistics, SAS Institute Inc., Cary, NC 1982.

Saloniemi, H., Y. Gröhn \& J. Syväjärvi: An epidemiological and genetic study on registered diseases in Finnish Ayrshire cattle. II. Reproductive disorders. Acta vet. scand. 1986, 27, 196-208.

Saloniemi, $H . \& K$. Roine: Incidence of some metabolic diseases in dairy cows. Nord. Vet.-Med. 1981, 33, 289-296.

Schwabe, $C$. W.: The current epidemiological revolution in veterinary medicine. Part I Prev. Vet. Med. 1982, 1, 5-15.

Solbu, $H .:$ Disease recording in Norwegian dairy cattle. I. Disease incidence and non-genetic effects on mastitis, ketosis, and milk fever. Z. Tierz. Zuechtungsbiol. 1983, 100, 139-156.

Solbu, $H$. .: Disease recording in Norwegian dairy cattle. II. Heritability estimates and progeny testing for mastits, ketosis and "all diseases”. Z. Tierzüchtg. Züchtsbiol. 1984, 101, 51-58.

Van Vleck, L. D.: Variation in type appraisal scores due to sire and herd effects. J. Dairy Sci. 1964, 47, 1249-1256.

\section{SAMMANFATTNING}

En epidemiologisk och genetisk undersökning av sjukdomsdata från finsk Ayrshire boskap. III. Metaboliska sjukdomar.

Epidemiologin av klinisk ketos, hypokalcemi och hypomagnesemi undersöktes. Den genetiska variationen av ketos och kalvningsförlamning undersöktes också. Dataset innehöll laktationsresultaten från 70775 finska Ayrshire kor. Varje ko observerades från 2 dagar före till 305 dagar efter kalvningen. Lactation incidence rate var: ketos 6,0 , paresis puerperalis 3,8 , icke-puerperal pares 0,6 , hypomagnesemi under betesperiod 0,6 och under stallperiod 0,2. Dessa sjukdomar omfattade $22 \%$ av alla första veterinärbehandlingar på gårdarna. $92 \%$ av ketosfallen infäll inom 8 veckor efter kalvningen. Den högsta frekvensen konstaterades $3-5$ veckor efter kalvningen. $4 \%$ av kalvningsförlamningarna inföll förkalvningen och $45 \%$ inom 24 timmar efter kalvningen. Ketosrisken var högre under stallperioden (oktoberapril) än under betesperioden (maj-september), när materialet klassificerades efter kalvningsmånaden. Paresrisken varierade inte signifikant efter kalvningsmånaden. Ketosfrekvensen ökade med laktationsperioder ända till fjärde kalvningen och minskade därefter. Paresrisken ökade med åldern. Hög mjölkproduktion hos både besättning och enskilda kor hade ett positivt samband med förekomsten av ketos och pares. Kor med tidigare infektion i reproduktionsorgan hade en 
högre risk att insjukna i ketos. Ärftligheten för ketos i olika laktationsperioder var från 1,6\% till 4,1\% i den binomala skalan (motsvarar från $18.3 \%$ till $27,4 \%$ ). Genetisk korrelation mellan ketos och pares och mellan dessa och mjölkproduktion varierade oregelbundet i olika laktationsperioder och en korrelation med hela materialet var osignifikant.

(Received February 6, 1986).

Reprints may be requested from: Yrjö Gröhn, the College of Veterinary Medicine, P. O. Box 6, 00551 Helsinki, Finland. 